\title{
Visualisasi Perempuan Dalam Perspektif AL-Qur'an: Antara Teks dan Konteks
}

\author{
Abdul Aziz \\ Sekolah Tinggi Nurul Iman, Parung Bogor \\ muheabdulaziz@gmail.com
}

\begin{abstract}
One of the missions in Al-Qur'an is to uphold justice between men and women. But the justice and equality mission that is in the Qur'an which is "wrapped up" in the statements of the verse, does not always literally show equality between men and women. Rather, it is the opposite that explicitly puts men in a superior position compared to women. The implicit statement and message of justice contained in the verses of the Qur'an also fades with the existence of classical interpretations that seem to prioritize men. Is there a mistake in the text or in how to understand it. This article aims to discuss how the provisions of the role of women in the Islamic view? The results of this study found that although normatively, the Qur'an and al-Hadith formulated several signs that must be obeyed by women, but that was undoubtedly perceived in a whole. Women in their role as social beings to be able to produce in the public, social and political realm. In this case Islam has regulated it, there is no limit that limits it if the woman has the ability to jump into the public domain, with a note that she is still paying attention to the syar'i signs that have been determined by Allah.
\end{abstract}

Abstrak: Salah satu misi dalam al-Qur'an adalah untuk menegakkan
keadilan antara laki-laki dan perempuan. Namun misi keadilan
dan kesetaraan yang ada dalam al-Qur'an yang "terbungkus"
dalam pernyataan-pernyataan ayatnya, tidak selamanya secara
harfiah menunjukan kesetaraan antara laki-laki dan perempuan. 
Melainkan sebaliknya yang secara tersurat menempatkan laki-laki pada posisi superior dibandingkan kaum perempuan. Pernyataan serta pesan keadilan yang implisit yang tertuang dalam ayat alQur'an juga bertambah samar dengan keberadaan tafsir klasik yang terkesan lebih mengutamakan laki-laki. Adakah kesalahan terletak pada teksnya ataukah pada cara memahaminya. Artikel ini bertujuan membahas bagaimana ketentuan peran perempuan dalam pandangan Islam? Hasil penelitian ini menemukan bahwa Meskipun secara normatif, al-Qur'an dan al-Hadits merumuskan beberapa rambu yang harus dipatuhi oleh para perempuan, namun hal itu niscaya dipersepsikan dalam suatu keutuhan. Perempuan dalam peranannya sebagai makhluk sosial untuk dapat berproduksi dalam ranah publik, sosial dan politik. Dalam hal ini Islam telah mengaturnya, tidak ada nash yang membatasinya apabila perempuan tersebut memiliki kemampuan terjun ke wilayah publik, dengan catatan tetap memperhatikan ramburambu syar'i yang telah ditentukan Allah.

Kata kunci: Kesetaraan, Perempuan, Islam

\section{A. Pendahuluan}

Masalah perempuan kini telah memperoleh perhatian yang cukup besar dari berbagai komunitas di seluruh dunia. Hal ini muncul karena adanya, kesadaran mengenai nasib dan kondisi perempuan yang selama ini tertindas serta mengalami perlakuan yang kurang adil oleh hegemoni sistem patriarki. ${ }^{1}$

Pada dekade terakhir ini pula semakin merebak perdebatan tentang ajaran agama yang berkaitan dengan perempuan. Terutama Islam, banyak orang yang mulai mempertanyakan ajaran-ajaran agama Islam yang terkesan bias gender. ${ }^{2}$ Dalam beberapa tradisi agama,

\footnotetext{
${ }^{1}$ Patriarchy adalah prinsip yang mendasari segala subordinasi, tidak hanya subordinasi perempuan pada kaum laki-laki, namun juga dominasi antara tuan dan yang dijajah, dominasi anak oleh orang tua, ataupun dominasi dalam bentuk hak monarki. Jadi patriarchy adalah semangat rasisme, kelas, kolonialisme, dericalisme, dan juga sexisme. Secara mendasar patriarchy adalah struktur kekuasaan atau kekuatan kelelakian di mana semua hubungan dipahami dalam term superior dan inferior. Yang menjadi korban patriarchy kalau begitu tidak hanya kaum perempuan, melainkan juga kaum laki-laki. Sandra Scheneider, Women and The World. (New York: Paulist Press, 1986).

${ }^{2}$ Untuk memahami konsep gender harus dibedakan kata gender dengan kata seks (jenis kelamin). Pengertian jenis kelamin merupakan pensifatan atau pembagian
} 
ditemukan beberapa hal yang terkesan mendeskreditkan perempuan. Islam, yang secara normatif mengajarkan kesetaraan laki-laki dan perempuan, tidak terlepas dari pemahaman yang bias gender ini. Hal ini mengundang tanda tanya di kalangan pemeluknya. Adakah kesalahan terletak pada teksnya ataukah pada cara memahaminya? ${ }^{3}$

Dengan kenyataan di atas, dunia ilmu tafsir al-Qur'an akhirakhir ini semakin berkembang dengan kemunculan mazhab feminism ${ }^{4}$ dalam menanggapi hal tersebut. Para feminis muslim dengan paradigma feminismenya menyatakan bahwa Al-Qur'an diwahyukan untuk menegakkan keadilan antara laki-laki dan perempuan. Namun misi keadilan dan kesetaraan yang ada dalam al-Qur'an yang "terbungkus" dalam pernyataan-pernyataan ayatnya, tidak selamanya secara harfiah menunjukkan kesetaraan antara laki-laki dan perempuan. Melainkan sebaliknya yang secara tersurat menempatkan laki-laki pada posisi superior dibandingkan kaum perempuan. Pernyataan serta pesan keadilan yang implisit dan tertuang dalam ayatayat al-Qur'an juga bertambah samar dengan keberadaan tafsir klasik, yang menurut feminis kurang memperhatikan faktor tersebut (secara tidak sadar terabaikan oleh tafsir klasik). Sehingga penafsiran klasik terhadap ayat-ayat tersebut dianggap hanya dan lebih menguntungkan laki-laki dan sebaliknya.

\section{B. Peran Perempuan Dalam al-Qur'an}

1. Peran Perempuan Sebagai Istri

Allah SWT menciptakan manusia berpasang-pasangan, ada laki-laki dan ada perempuan. Secara naluri kemanusiaan keduanya saling membutuhkan, terutama sangat jelas pada kematangan seksual.

dua jenis kelamin tertentu. Sedangkan konsep gender adalah suatu sifat yang melekat pada kaum laki-laki maupun perempuan yang dikonstruksi secara sosial maupun kultural. Julia Cleves Mosse, Gender Dan Pembangunan, trans. H. Silawati (Yogyakarta: Rifka An-Nisa WCC dan Pustaka Pelajar, 1996), h.3-4.

${ }^{3}$ Nasaruddin Umar, Bias Gender Dalam Pemahaman Islam (Yogyakarta: Gama Media, 2002), h.v.

${ }^{4}$ Gerakan feminisme sebagai gerakan perempuan dalam memperjuangkan kedudukannya supaya sejajar dengan laki-laki baru muncul sebagai istilah pada tahun 1880. Lihat Syafiq Hasyim, ed., "Gerakan Perempuan Dalam Islam: Perspektif Kesejarahan Kontemporer”, Dalam Taswīr Al-Afkār, V (Jakarta: Lakpesdam dan LTN-NU, 1999), h.4. 
Anjuran untuk menikahkan keluarga yang masih membujang padahal kemampuan untuk menikah telah ada.

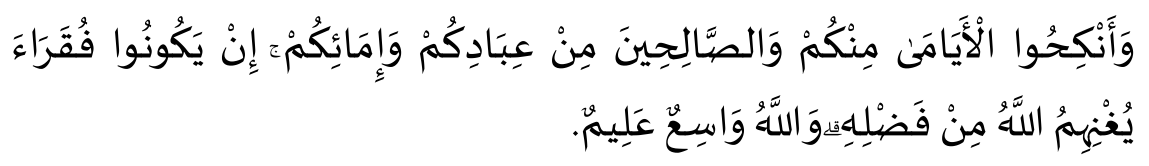

"Dan kawinkanlah orang-orang yang sedirian diantara kamu, dan orang-orang yang layak (berkawin) dari hamba-hamba sahayamu yang lelaki dan hamba-hamba sahayamu yang perempuan. jika mereka miskin Allah akan memampukan mereka dengan kurnia-Nya. dan Allah Maha Luas (pemberianNya) lagi Maha mengetahui”. (QS. al-Nūr [24]: 32).

Al-Khazin menguraikan ayat ini bahwa al-ayāmā yang merupakan jama' dari al-aimu menunjuk pada laki-laki maupun perempuan yang tidak atau yang belum memilki pasangan hidup. ${ }^{5}$ Lebih lanjut, al-Khazin dalam menafsirkan ayat tersebut mengutip pendapat Sayyidina 'Umar bin Khattab bahwa mengherankan sekali orang yang berharap memperoleh kekayaan, tetapi tidak mau menikah, padahal, orang yang menikah itu berarti mengumpulkan dua rezeki, rezeki suami dan istri. ${ }^{6}$ Jadi sebenarnya tidak ada alasan kuat seseorang takut atau terus menunda-nunda pernikahan. Terdapat banyak hadits Rasulullah SAW. Yang menganjurkan pernikahan apabila telah mampu untuk itu, bahkan beliau menganggap orang yang tidak mau menikah berarti tidak mau mengikuti sunnahnya. ${ }^{7}$

Setelah pernikahan berlangsung yang ditandai ole hijab dan Kabul, maka serta peran sebagai suami dan istri dimulai. Istri harus

5 'Alā'uddin 'Ali bin Muhammad al-Khazin, Lubāb At-Ta'wīl Fì Ma'āni atTanzīl (t.t.: t.p, t.th.), h.2.

${ }^{6}$ Ibid.

${ }^{7}$ Salah Satu Diantaranya, Hadits Yang Diriwayatkan Oleh Imam Bukhari Dan Muslim: (Wahai Para Pemuda, Barangsiapa Diantara Kamu Yang Sudah Mampu Menikah, Maka Nikahlah, Karena Sesungguhnya Nikah Itu Lebih Dapat Menundukkan Pandangan Dan Lebih Dapat Menjaga Kemaluan. Dan Barangsiapa Yang Belum Mampu, Maka Hendaklah Ia Berpuasa, Karena Berpuasa Itu Baginya (Menjadi) Pengekang Syahwat). Lihat Bukhari, Shahih al-Bukhārī, Juz 6, Hal. 476, Hadits Nomor 1772; Muslim, Shahih Muslim, Juz 7, Hal. 173, Hadits Nomor 2485., n.d. 
memposisikan diri sebagai seorang istri dari suaminya yang memiliki hak dan kewajiban, begitu pula sebaliknya. Kalau kedua belah pihak menyadari posisi dan peran masing-masing, maka rumah tangga itu akan berjalan harmonis. Istri memiliki peran strategis di rumah tangganya, antara lain karena secara umum istrilah yang memiliki banyak waktu di rumah mengurus rumah tangga dan anak-anak. ${ }^{8}$ Bahwa ada yang mensubstitusi kepada orang lain adalah masalah lain. Beberapa peran istri dapat dikemukakan antara lain:

a. Menjadi pasangan suaminya (secara biologis)

Ketika Adam belum memiliki pasangan di awal kehidupanya, ia merasakan sangat kesepian, maka Allah SWT. Menciptakan Hawa yang kemudian menjadi istrinya dan melahirkan anak-anaknya. ${ }^{9}$ Tidak dapat diingkari bahwa salah satu kebutuhan biologis manusia adalah melakukan aktivitas reproduksi. ${ }^{10}$ Pada aktivitas ini Allah SWT. Meletakkan kenikmatan agar manusia senang melakukanya.

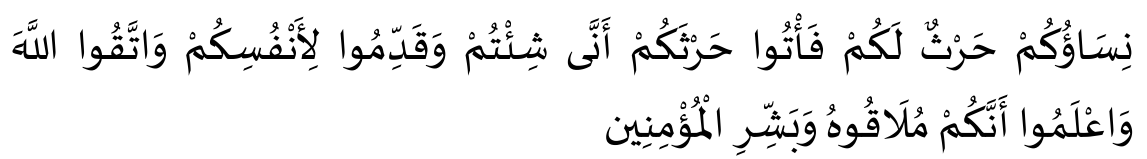

"Isteri-isterimu adalah (seperti) tanah tempat kamu bercocok tanam, Maka datangilah tanah tempat bercocok-tanammu itu bagaimana saja kamu kehendaki. dan kerjakanlah (amal yang baik) untuk dirimu, dan bertakwalah kepada Allah dan ketahuilah bahwa kamu kelak akan menemui-Nya. dan berilah kabar gembira orang-orang yang beriman" (QS. al-Baqarah/2: 223).

Pada umumnya ulama tafsir memahami ayat ini sebagai kebolehan mendatangi istri dengan cara yang menyenangkan. Dalam Tafsìr Aisar al-Tafsìr misalnya, disebutkan bahwa tidak ada dosa bagi bagi suami yang mendatangi istrinya dengan berbagai cara yang diingini sepanjang di tempat yang seharusnya untuk reproduksi (maudhi' an-

${ }^{8}$ Depag RI, “Tafsir Al-Qur'an Tematik” (Jakarta: Lajnah Pentashih Mushaf Al-Qur'an, 2009), h.193-194.

${ }^{9}$ Abu Muhammad al-Andalusi, Al-Muharrir al-Wajiz, 2 (t.t: t.p, t.th), h.67; Muhammad bin Jarir Al-Thabariy, Jami' al-Bayān F̄̄ Ta'wīl Al-Qur'ān, 1 (t.t: Muassasah ar-Risālah, t.th), h.513 Dalam teks aslinya yang dikutiup dari riwayat Murrah: ( فكان يمشي فيها وحشا ليس لله زوج يسكن ... إليها ).

10 Musdah Mulia, Membangun Surga Di Bumi; Kiat-Kiat Membina Keluarga Islam Di Bumi (Jakarta: PT Elex Me dia Komputindo, 2011), h.281.

Analisis: Jurnal Studi Keislaman, Volume 17, No. 2 Tahun 2017 
Nasl). ${ }^{11}$ Bahkan, variasi-variasi itu diperlukan untuk menghilangkan kebosanan sepanjang dapat dinikmati berdua dan tidak ada unsur pemaksaan (pemerkosaan). Istri harus berupaya untuk menjadi partner yang baik terhadap pasangannya, bahkan tidak di perkenankan menolak ajakan suaminya untuk memenuhi hasrat biologis yang telah dihalalkan oleh Allah SWT., sebab jikalau menolak berarti ia telah mengabaikan salah satu perannya sebagai istri, yaitu menjadi pasangan suaminya secara biologis. ${ }^{12}$

b. Menjadi pasangan suaminya (secara psikologis)

Peran lain perempuan sebagai istri adalah menjadi pasangan suaminya dalam hal-hal yang bersifat psikologis. Istri yang baik (sālihah) adalah istri yang mampu mengaktualisasikan dirinya dengan baik sehingga suaminya senantiasa memperoleh kesenangan secara psikologis. Istri yang menjalankan peranya dengan baik sehingga menjadi istri salihah bagi suaminya diumpamakan seperti mahkota emas di atas kepala raja, sementara istri yang tidak menjalankan peranya laksana beban berat di atas punggung kakek tua. ${ }^{13}$

Salah satu kebahagiaan bagi suami apabila ia mempunyai pasangan (istri) yang salihah. Ia menjadi milik berharga (heritage) bagi suaminya. Sabda Rasulullah SAW.

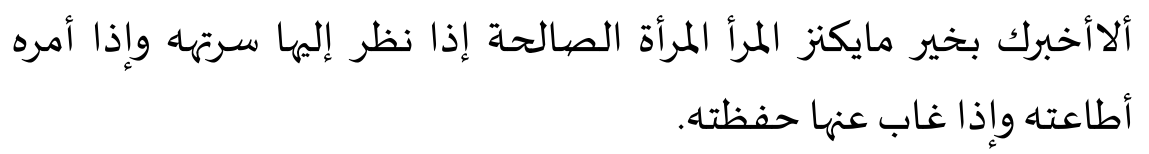

"Ingatlah kamu aku beritahu suatu kebaikan yang didambakan. Untuk dimilki umat manusia (suami)? Jawabnya adalah perempuan yang salihah, yaitu apabila suami memandangnya ia menggairahkan, jika suami menyuruhnya ia menaatinya, dan jika suaminya tidak di sampingnya ia memelihara dirinya. ${ }^{14}$

${ }^{11}$ Ibrahim al-Qatān, Aisar At-Tafsīr (t.t: t.p, t.th), h.126.

12 Musdah Mulia, Membangun Surga Di Bumi; Kiat-Kiat Membina Keluarga Islam Di Bumi, h.253.

${ }^{13}$ Abu Bakar bin Abi Syaibah, Al-Musannif, n.d., juz 3, h.399.

${ }^{14}$ Abu Daud, Sunan Abū Daud (t.t: t.p, t.th), h. hadits nomor 1417. 
c. Menjadi manajer dalam mengatur rumah tangga

Rumah adalah tempat tinggal bagi keluarga untuk istirahat, berkumpul, dan melakukan berbagai aktivitas personal dan sosial antar anggota keluarga setiap hari. Begitu pentingnya rumah sebagai tempat tinggal yang menyenangkan bagi semua sehingga ada ungkapan yang menjadi daman bagi semua orang: "baitī jannat̄̄ "(rumahku adalah surgaku). ${ }^{15}$ Namun yang terpenting bagaiman rumah itu fungsional untuk berbagai keperluan rutin sehari-hari dimana rumah sebagai tempat tinggal (QS. Al-Nahl/16: 80).

Dalam upaya mewujudkan tempat tinggal yang nyaman bagi istana itu, peran istri sangat menetukan. Jika suami lebih banyak bekerja di luar rumah, maka istri berperan dalam mengatur rumah tangganya. Karena itu, tidak berlebihan jika istri disebut sebagai manajer dalam mengatur rumah tangganya. Sebagai manajer ia berperan menata berbagai sarana yang diperlukan oleh semua anggota keluarga sehingga fungsional dan menyenangkan, mengatur urusan belanja sehari-hari sehingga tertata dan terprogram dengan baik. Salah satu hadits Rasulullah SAW. yang mendukung program ini adalah:

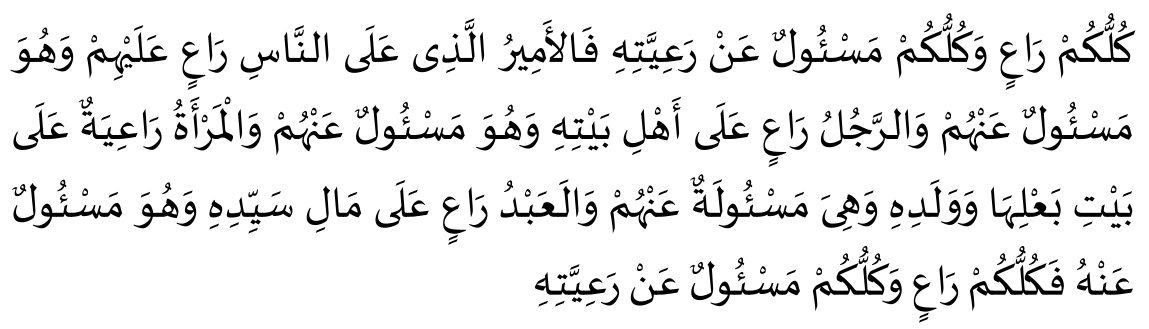

"Ketahuilah...Setiap dari kalian adalah pemimpin yang akan di mintai pertanggung jawabannya, seorang imam adalah pemimpin bagi masyarakatnya dan akan di mintai pertanggung jawabanya tentang kepimpinannya, seorang suami adalah pemimpin bagi keluarga dan ia bertanggung jawab terhadap keluarganya, seorang istri adalah pemimpin bagi rumah suaminya dan anak-anaknya dan ia bertanggung jawab terhadap mereka, seorang pembantu adalah pemimpin bagi harta tuannya dan ia bertanggung jawab terhadapnya, setiap kalian adalah pemimpin dan tiap kalian mempunyai

15 Musdah Mulia, Membangun Surga Di Bumi; Kiat-Kiat Membina Keluarga Islam Di Bumi, h.59.

Analisis: Jurnal Studi Keislaman, Volume 17, No. 2 Tahun 2017 
tanggung jawab terhadap yang di pimpinnya”. (HR. alBukhari dari Ibnu Umar) ${ }^{16}$

Peran perempuan dalam wilayah domestik ini menjadi menjadi sangat dominan. Ungkapan "perempuan sebagai pemimpin dalam rumah suaminya dan bertanggung jawab terhadap wilayah tugasnya" memberi jaminan akan peran strategis ini. Peran istri dalam mengatur rumah tangga meliputi segala upaya yang memberi akses, kenyamanan, keamanan, privasi, dan kebebasan bagi semua anggota keluarga dalam memanfaatkan fasilitas yang ada dalam rumah tangga.

2. Peran Perempuan Sebagai Ibu

Ada ungkapan yang menyebutkan "al-ummu madrastul ūlā" (ibu adalah sekolah pertama) untuk menunjukkan betapa peran ibu sangat setrategis dalam mendidik anak-anaknya di awal kehidupan mereka. ${ }^{17}$ Orang pertama yang sudah pasti ditemui oleh anak yang lahir di dunia ini adalah ibunya. Ibu tidak dapat disangsikan statusnya sebagai ibu dari anak-anaknya pada saat ia melahirkan. Dalam pengurusan dokumen seperti kartu kredit, yang diperlukan untuk data adalah nama ibu kandung, karena secara biologis ibu kandung bersifat pasti (QS. Al-Ahqāf/46: 15). ${ }^{18}$

Secara garis besar peran perempuan sebagai ibu dapat dijelaskan beberapa diantaranya sebagai berikut:

a. Mengandung Anak

Salah satu kodrat perempuan adalah mengandung anakanaknya.

Dan Kami perintahkan kepada manusia (berbuat baik) kepada dua orang ibu- bapanya; ibunya telah mengandungnya dalam Keadaan lemah yang bertambah- tambah, dan menyapihnya dalam dua tahun. bersyukurlah kepadaku dan kepada dua orang ibu bapakmu, hanya kepada-Kulah kembalimu. (QS. Luqmān/31: 14).

16 Abu 'Abdillah bin Muhammad Al-Bukhari, Shahih Al-Bukhārī (Singapura: Sulaiman, t.th),Juz 3, h.44 hadits nomor 8444.

17 Musdah Mulia, Membangun Surga Di Bumi; Kiat-Kiat Membina Keluarga Islam Di Bumi, h.112-113.

${ }^{18}$ Depag RI, “Tafsir Al-Qur'an Tematik,” h.201. 
Kata al-wahn diartikan sebagai kelelahan atau kelemahan fisikdan mental. Ungkapan ini disebut bergandengan setelah wasiat kepada manusia agar berbuat baik kepada orang tuanya sebagai penguat tentang hak-hak mereka terutama ibunya yang telah melewati berbagai kesulitan dalam mengandung, melahirkan, dan merawat anakanaknya. ${ }^{19}$

\section{b. Melahirkan dan menyusui}

Anak lahir ke dunia telah dilengkapi oleh Allah SWT. berbagai modalitas untuk hidup seperti insting (naluri) untuk menyusu, tapi belum memiliki pengetahuan dan kecerdasan (kognitif) kecuali potensi-potensi yang siap dikembangkan oleh orang tua dan lingkungannya.

Dan Allah mengeluarkan kamu dari perut ibumu dalam Keadaan tidak mengetahui sesuatupun, dan Dia memberi kamu pendengaran, penglihatan dan hati, agar kamu bersyukur. (QS. Al-Nahl/16: 78).

Sesuatu yang menakjubkan adalah ketika seorang ibu malahirkan anaknya, bersamaan dengan itu pula ia memproduksi air susu yang siap dikonsumsi sebagai nutrisi yang sehat sebagai bayinya. Air susu ibu telah dibuktikan oleh ilmu pengetahuan modern sebagai makanan sehat terbaik bagi bayi. Komposisinya sangat pas dengan kebutuhan bayi dalam pertumbuhan dan perkembangannya. Anak yang minum ASI memiliki tingkat kekebalan lebih tinggi terhadap berbagai penyakit ketimbang bayi yang hanya mengonsumsi susu formula. Wajar jika Al-Qur'an menganjurkan para ibu untuk menyusukan anaknya selama dua tahun (QS. al-Baqarah/2]: 233, Lihat juga QS. Lukmān/31]: 14, QS. al-Ahqāaf/46]: 15).

Dalam sebuah riwayat juga disebutkan: "Kewajiban orang tua terhadap anaknya antara lain mengajarinya tulis-baca, berenang, memanah dan tidak memberinya rezeki kecuali yang baik (halal) (HR. al-Hakim dan al-Baihaki dari Abu Rafi') ${ }^{20}$ Dalam Tafsīr al-Muyassar

\section{h.3363.}

19 Muhammada Sayid Tantawi, Al-Tafsīr Al-Wasìt (t.t: t.p, t.th), Juz 1,

${ }^{20}$ Hadits Ini Diriwayatkan Oleh Al-Hakim Dan Al-Baihaki Dari Abu Rafi', Lihat Jami' Al-Hadīts, Juz 12, Hal. 134. Dalam Riwayat Ibnu as-Sinni Lafalya Adalah , Status Hadits Ini Menurut Al-Bani Dalam Kitab Shahīh Wa Da'îf AlJami' as-Shaghīr , Juz 14, Hal. 275, Adalah Sangat Lemah (Da'îf Jiddan). Namun Ditemukan Juga Banyak Riwayat Yang Mendukungnya.., n.d. 
dijelaskan bahwa seseorang harus merasa khawatir kalau-kalau sesudah wafatnya ia meninggalkan anak keturunan yang lemah, lalu mereka teraniaya dan kehilangan segalanya (tak bermakna dalam kehidupan, meaningless). Untuk itu penting untuk menjaga harta mereka, memberikan pendidikan terbaik, menjauhkan mereka dari segala penderitaan, dan senantasa berkomunikasi secara baik dan adil. $^{21}$

Oleh karena itu penulis menghimbau bahwa tarbiyah terhadap anak hendaknya telah dimulai sejak sang buah hati masih dalam kandungan ibu. Walaupun jenis tarbiyah ini masih bersifat permulaan, namun hal ini juga membantu dalam pembentukan kepribadian anak kelak. Jika kita lihat dari ilmu kedokteran, ketika janin telah berusia 14 minggu, panca indranya telah mulai berkembang hingga mencapai fungsi yang sempurna sampai waktu bayi siap untuk dilahirkan.

3. Peran Perempuan dalam Bidang Sosial

a. Pandangan Ulama Terkait Perempuan Harus Tetap Tinggal di Rumah

Di antara ayat yang dapat mengantarkan kepada kesimpulan bahwa seorang perempuan, lebih khusus lagi adalah istri, harus tetap tinggal di rumah adalah isyarah firman Allah swt.: "Dan hendaklah kamu tetap di rumahmu dan janganlah kamu berhias dan bertingkah laku seperti orang-orang Jahiliyah yang dahulu dan dirikanlah shalat, tunaikanlah zakat dan taatilah Allah dan Rasul-Nya. Sesungguhnya Allah bermaksud hendak menghilangkan dosa dari kamu, Hai ahlul bait dan membersihkan kamu sebersih-bersihnya." QS. Al-Ahzāb/33: 33.

Para mufsir berbeda pendapat tentang makna ayat tersebut. AlQurtubiy (w. 671), salah seorang mufasir yang bercorak hukum, memberi penjelasan: "makna ayat tersebut adalah perintah untuk menetap di rumah walaupun redaksi ayat ini ditujukan kepada isteriistri Nabi Muhammad Saw, tetapi selain dari mereka juga tercakup dalam perintah tersebut." 22

${ }^{21}$ Tim ulama tafsir di bawah supervise Dr. Abdullah bin Abdul Muhsin atTurki, Tafsīr Muyassar, (t.t: t.p, t.th), Juz 2, h.9.

${ }^{22} \mathrm{Abu}$ 'Abdillah Muhammad bin Ahmad al-Anshari Al-Qurtubi, Al-Jami' Li Ahkām Al-Qur'ān (Beirut: al-Maktabah al-Asriyyah, 2005), h.28. 
Pendapat lebih moderat disampikan oleh Ibn Katsir, (w. 774 H). Dalam pandanganya ayat tersebut merupakan halangan bagi perempuan khususnya istri Nabi Saw. Dan perempuan muslimah lainya untuk keluar rumah jika tidak ada kebutuhan yang dibenarkan agama, shalat di masjid misalnya, ${ }^{23}$ Dari kelompok mufasir kontemporer yang berpandangan seperti di atas adalah Wahbah azZuhaili yang menyatakan: "hendaklah perempuan tetap tinggal di rumah, jangan sering keluar rumah tanpa ada keperluan yang dibolehkan agama". ${ }^{24}$ Sedangkan diantara para pemikir kontemporer adalah al-Maudududi yang berpandangan seperti di atas. Dalam bukunya al-Hijab seperti yang dikutip oleh Muhammad Quraish Shihab, al-Maududi menyatakan:

"Tempat perempuan adalah di rumah, mereka tidak dibebaskan dari pekerjaan di luar rumah kecuali agar mereka selalu berada di rumah dengan tenang dan hormat, sehingga mereka dapat melaksanakan kewajiban rumah tangga. Adapun kalau ada hajat keperluanya untuk keluar, maka boleh saja mereka keluar rumah dengan syarat memperhatikan kesucian diri dan memelihara rasa malu." ${ }^{25}$ Pandangan senada diberikan Tim Penyusun Tafsir Departemen Agama RI yang memberi penjelasan agama bahwa istri Nabi Saw. Agar tetap tinggal di rumah mereka masing-masing kecuali apabila ada keperluan." 26

Pandangan yang berbeda diberikan oleh Sayyid Qutub dan M. Quraish Shihab. Dalam Tafsirnya Fì Dzilāl Al-Qur'ān, Sayyid Qutub menyatakan ayat tersebut memberi isyarat bahwa rumah tangga adalah tugas pokok para istri, sedangkan selain itu adalah tempat ia tidak menetap alias bukan tugas pokoknya. ${ }^{27}$ Sementara Muhammad Quraish Shihab nampaknya cenderung terhadap pendapat Sayyid Qutub tersebut dengan memberikan argument tambahan yang dikutip dari cendikiawan Mesir lainya, Muhammad Qutub, yang menyatakan bahwa perempauan pada zaman awalpun bekarja, ketika kondisi

\footnotetext{
${ }^{23}$ Ibnu Katsir, Tafsīr Al-Qur'ān al-Karīm. (Beirut: Dār al-Fikr, 1980), h.93.

${ }^{24}$ Wahbah Zuhaili, Tafsīr Wajīz (t.t: t.p, t.th), h.423.

${ }^{25}$ M. Quraish Shihab, Wawasan Al-Qur'an (Bandung: Mizan, 1996), h.304.

${ }^{26}$ Tafsir Depag RI(Jakarta: Balitbang Agama, 2004), h.5.

${ }^{27}$ Sayyid Qutub, F̄̄ Dzilāl Al-Qur'ān (Beirut: Dār asy-Syurūq, n.d.), h.7.
} 
menuntut mereka untuk bekerja. Masalahnya bukan terletak ada atau tidaknya hak mereka untuk bekerja, masalahnya adalah bahwa Islam tidak cenderung mendorong perempuan keluar kecuali untuk pekerjaan pekerjaan yang sangat perlu yang dibutuhkan oleh masyarakat, atau atas dasr kebutuhan tertentu. Misalnya kebutuhan bekerja karena tidak ada yang membiayai hidupnya, atau karena yang menananggung hidupnya tidak mampu untuk mencukupi kehidupanya. ${ }^{28}$

Dari pandangan ulama di atas ada dua hal yang perlu digaris bawahi menyangkut sebab perbedaan tersebut; Pertama, menyangkut kebahasaan dari kata waqarna. Kedua, diantara izin keluar rumah karena alasan darurat, atau ada keperluan yang dibenarkan agama atau keperluan apa saja? (apa batasanya). Kata waqarna dalam ayat tersebut oleh para mufasir diperselisihkan akar katanya. Sementara ulama berpendapat bahwa kata tersebut berasal dari kata qarna (dibaca fathah pada huruf qaf). Seperti yang dibaca oleh Imam 'Asim berasal dari kata iqirna yang mangandung arti "tinggalah dan beradalah di tempat." Sementara ada yang membaca qirna (kasrah pada huruf qaf) yang berasal dari kata qarār yang berarti "berada di tempat." 29 "Abdullah Yusf "Ali menerjemahkan kata tersebut dengan "stay quietly in your house." 30 Kata stay oleh AS Hornby dalam kamus Oxford diberikan arti sebagai "remain, continiusly in place or condition (for long or short time, permanently or temporarily). ${ }^{31}$ Dalam penelusuran terhadap sejarah didapati praktik hidup kaum perempuan pada masa Rasulullah Saw. Ternyata banyak yang terlibat dalam aktivitasaktivitas sosial kaum perempuan. ${ }^{32}$ Menurut hemat penulis perempuan memiliki porsi yang sama di tengah-tengah masyarakat, dia memiliki kedudukan yang sama dengan laki-laki. Dia tidak harus tetap tinggal di rumah bilamana keberadaanya memang sangat dibutuhkan oleh masyarakat, walaupun memang secara ideal dia lebih baik di dalam rumah.

${ }^{28}$ M. Quraish Shihab, Tafsir Al-Misbah (Jakarta: Lentera Hati, 2002), h.267.

${ }_{29}$ Ar-Raghib al-Ishfahani, Mu'jam al-Mufradāt Alfād Al-Qur'ān (Beirut: Dār al-Fikr, t.th), h.397.

${ }^{30}$ Abdullah Yusuf 'Ali, The Meaning of Holy Al-Qur'ān, ( (Beirut: Dār al'Arabiyyah, t.th), h.1066.

${ }^{31}$ AS Hornby, "Oxford Dictionar," n.d., h.844.

${ }^{32}$ Depag RI, “Tafsir Al-Qur'an Tematik," h.130. 


\section{b. Perempuan Bekerja di Luar Rumah}

Dalam kamus besar bahasa Indonesia "kerja" diartikan sebagai "kegiatan melakukan sesuatu atau sesuatu yang dilakukan untuk mencari nafkah." 33 Sedangkan dalam bahasa Al-Qur'an, kata "kerja" sering diidentikan dengan kata 'amal. Secara leksikal menurut Ibnu Faris dalam Mu'jam Maqāyis al-Lugah, kata 'amal mengandung arti "perbuatan, pekerjaan, aktivitas." 34 Sedangkan secara terminologis kata tersebut oleh al-Isfahani diartikan sebagai "perbuatan atau aktivitas yang dilakukan secara sadar dan sengaja, bersumber pada daya yang dimiliki manusia; daya fisik, daya fikir, daya kalbu, dan daya hidup." ${ }^{35}$ Kata ini dengan segala segala perubahanya di dalam AlQur'an terulang sebanyak 359 kali. Secara garis besar dapat di bagi menjadi dua; pekerjaan yang baik ('amal shalih) dan pekerjaan yang tidak baik ('amal gairu shalih). Ini dapat dilacak pengertian kerja yang baik dan kaitanya dengan yang dilakukan perempuan.

Kata salih dengan semua perubahanya terulang di dalam AlQur'an sebanyak 180 kali, ${ }^{36}$ yang oleh al-Raghib secara umum dapat dikelompokkan menjadi dua bentuk, yaitu bentuk transitif (membutuhkan objek) dan intransitive (tidak membutuhkan objek). ${ }^{37}$ Kriteria yang menjadikan sebuah aktivitas itu dikatakan shalih tidak dijelaskan oleh Al-Qur'an sehingga para mufasir berbeda pendapat. Al-Zamakhsyari mengartikan amal yang shalih adalah "segala perbuatan yang sesuai dengan dalil akal, Al-Qur'an dan Sunnah Rasulullah SAW. ${ }^{38}$

Sementara Muhammad 'Abduh mendefinisikan amal salih sebagai "segala perbuatan yang berguna bagi pribadi, keluarga, kelompok, dan manusia secara keseluruhan. ${ }^{39}$ Untuk mencari penjelasan Al-Qur'an tentang kriteria aktivitas yang sāleh dapat

33 Departemen Pendidikan dan Kebudayaan, "Kamus Besar Bahasa Indonesia" (Jakarta: Balai Pustaka, 1995), h.554.

${ }^{34}$ Ibnu Faris, Mu'jam al-Maqāyis al-Lugah, n.d., h.677.

35 Ibid., h.574; Ar-Raghib al-Ishfahani, Mu'jam al-Mufradāt Alfād AlQur'ān, h.284.

${ }^{36}$ Muhammad Fuad Abdul Baqi, Mu'jam al-Mufahras, n.d., h.520-523.

${ }^{37}$ Ar-Raghib al-Ishfahani, Mu'jam al-Mufradāt Alfäd Al-Qur'ān, h.284-285.

${ }^{38}$ Az-Zamakhsyari, Al-Kasysyāf (Mesir: Musthafa al-Bābi al-Halabī, 1996), h.321.

${ }^{39}$ Muhammad 'Abduh, Tafsīr Juz 'Amma (Beirut: Dār al-Fikr, n.d.), h. 
menelusuri kata tersebut yaitu fas $\bar{a} d$. Dengan melakukan perbuatan yang sebaliknya dari aktivitas yang disebit făsid, ini dapat diartikan sebagai aktivitas yang saleh.

Beberapa contoh yang dapat dikelompokkan sebagai perbuatan yang fâsid antar lain: Pertama, perusakan flora, generasi manusia, dan ekosistem, antara lain diisyaratkan dalam Surah alBaqarah/2: 205. Kedua, menolak untuk menerima kebenaran, antara lain diisyaratkan dalam Surah Āli 'Imrān/3: 63. Ketiga, perampokan pembunuhan, dan gangguan keamanan hal ini disebutkan dalam Surah al-Māidah/5: 32. Keempat, pengurangan takaran, timbangan, dan hakhak manusia, isyarat ini dapat ditemukan di dalam Surah al-A'rāf/7: 86. Kelima, usaha memecah belah kesatuan, Surah al-Anfāl/8: 73. Keenam, bermewah-mewah dan berfoya-foya, diisyaratkan dalam Surah Hūd/11: 116. Ketujuh, pemborosan, ini diisyarahkan dalam Surah asy-Syu'arā'/42: 151-152. Kedelapan, perbuatan makar dan penipuan, Surah an-Namal/27: 48. Kesembilan, menukar nilai-nilai agama, Surah al-Gāfir/40: 26. Kesepuluh, sikap sewenang-wenang, Surah al-Fajr/89: 11-12.

Dari penelusuran di atas dapat disimpulkan bahwa ayat-ayat yang berbicara tentanf fäsid di atas dapat disimpulkan bahwa setipa usaha untuk mencegah terjadinya hal-hal tersebut di atas, dapat dikatakan sebagai perbuatan yang shalih. ${ }^{40}$

\section{c. Bekerja adalah keniscayaan hidup}

Tujuan utama Allah SWT. Memberikan kesempatan hidup di dunia adalah agar manusia-termasuk perempuan-bekerja dengan baik. Hal ini diisyartkan dalam firmanya: "Yang menjadikan mati dan hidup, supaya Dia menguji kamu, siapa di antara kamu yang lebih baik amalnya. dan Dia Maha Perkasa lagi Maha Pengampun. (QS. AlMulk/6: 2)".

Dalam ayat tersebut setiap orang, baik laki-laki maupun perempuan, dituntut untuk dapat mengerahkan kemampuan terbaiknya dalam bekerja dan melakukan tugas-tugasnya. Maka jikalau ada orang yang enggan untuk berusaha, apalagi kalau itu adalah tugas utamanya

${ }^{40}$ Namun demikian yang cukup menarik adalah bahwa dalam Al-Qur'an tidak selamanyamenggunakan kata fāsid sebagai antonimnya. Ada satu ayat yang menggunakan kata sayyi'a sebagai antonimnya, yaitu dalam Surah at-Taubah/9: 102 n.d. 
baik laki-laki maupun perempuan, sungguh orang tersebut telah melalaikan kewajiban utamanya ini.

d. Memiliki kesempatan yang sama untuk berprestasi

Ayat yang secara jelas menunjukkan hal tersebut adalah dalam firmanya:

"Dan janganlah kamu iri hati terhadap apa yang dikaruniakan Allah kepada sebahagian kamu lebih banyak dari sebahagian yang lain. (karena) bagi orang laki-laki ada bahagian dari pada apa yang mereka usahakan, dan bagi Para perempuan (pun) ada bahagian dari apa yang mereka usahakan, dan mohonlah kepada Allah sebagian dari karunia-Nya. Sesungguhnya Allah Maha mengetahui segala sesuatu”. (QS. al-Nisā'/4: 32).

Abu Hayyan memberikan komentar ayat tersebut dengan menyatakan bahwa "Islam tidak menerima orang yang hanya berangan-angan dan berpangku tangan. Tidak pula memperkenankan sikap pasif dan malas. Islam menyerukan sikap yang progresif dan kerja keras. Adapun berangan-angan terhadap hal-hal yang baik di dunia dan berusaha mewujudkan dengan tujuan mendapat pahala akhirat, maka yang seperti itu sangat terpuji. Seseorang yang menggantungkan keberuntungannya dengan giat bekerja adalah spirit Islam. ${ }^{41}$

Pandangan yang lebih tegas diberikan oleh Rasid Ridha yang menyatakan, "ayat tersebut tidak melarang seseorang untuk mewujudkan kemampuan terbaiknya." Sebab tidak ada salahnya apabila ada orang yang tergiur melihat prestasi orang lain kemudian berusaha meraih hal tersebut dengan bekerja keras. Mengharapkan kelebihan tersebut tidaklah dilakukan kecuali oleh orang yang mlemah akalnya dan kerdil jiwanya. ${ }^{42}$ Dengan kalimat yang singkat namun padat Ibnu asy-Syur menyatakan "Setiap manusia laki-laki maupun perempuan berhak mendapatkan bagiannya dalam menikmati fasilitas duniawi yangh diperuntukkan baginya sebagai balasan atas kerja kerasnya atau sebagian usaha yang telah ia lakukan. ${ }^{, 43}$ Berikut ini ayat

\footnotetext{
${ }^{41}$ Abu Hayyan, Bahr Al-Muhìt (t.t: t.p, t.th), h.235.

${ }^{42}$ Rasyid Ridha, Tafsīr Al-Manār (Beirut: Maktabah al-Qāhirah, t.th), h.42.

${ }^{43}$ Muhammad at-Tahir Ibnu asy-Syur, Tahrīr Wa Tanwīr ( (t.t: t.p, t.th), h.
} 
yang dengan tegas mengemukakan tentang keadilan bagi laki-laki maupun perempuan untuk berkarir dan berpretasi: ${ }^{44}$

"Barangsiapa yang mengerjakan amal saleh, baik laki-laki maupun perempuan dalam Keadaan beriman, Maka Sesungguhnya akan Kami berikan kepadanya kehidupan yang baik dan Sesungguhnya akan Kami beri Balasan kepada mereka dengan pahala yang lebih baik dari apa yang telah mereka kerjakan”. (QS. Al-Nahl/16: 97).

Dari penjelasan di atas dapat disimpulkan bahwa tidak ada teks ayat maupun hadits Nabi yang secara tegas melarang perempuan untuk bekerja di luar rumah sekalipun. Oleh karena itu, pelarangan terhadap perempuan untuk bekerja adalah kurang tepat. Kaidah agama mengajarkan "Dalam hal kemasyarakatan pada dasarnya semua boleh selama tidak ada larangan, sebaliknya dalam hal ibadah mahdah semuanya terlarang selama tidak ada tuntutanya." 45

Mencari nafkah pada dasarnya adalah tanggung jawab lakilaki, namun apabila kondisi mengharuskan perempuan untuk bekerja di luar rumah demi mencukupi kebutuhan keluarganya maka dalam hal ini perempuan hukumnya wajib melakukan pekerjaan itu.

4. Kewajiban Perempuan Menuntut Ilmu

Uraian tentang kewajiban perempuan menuntut ilmu, dapat dimulai dari apresiasi Al-Qur'an terhadap ilmu pengetahuan. Ini dapat dimulai dari melihat betapa seringnya Al-Qur'an menyebut kata 'ilm (yang berarti pengetahuan) dengan segala derivasinya (pecahanya) yang mencapai lebih dari 800-an kali. Belum lagi ungkapan lain yang dapat memilki kesamaan makna menunjuk arti pengetahuan, seperti; kata al-fikr, al-nadzr, al-basar, al-tadabbur, al-zikr, dll. Kata 'ilm menurut para ahli bahasa Al-Qur'an mengandung arti "pengetahuan akan hakikat sesuatu." 46

Dari kata kunci inilah kita dapat mulai melacak bagaiman AlQur'an khususnya dan agama Islam pada umumnya memberikan perhatian terhadap ilmu pengetahuan. Diantaranya adalah:

${ }^{45}$ Depag RI, “Tafsir Al-Qur'an Tematik,” h.238.

${ }^{46}$ Ar-Raghib al-Ishfahani, Mu'jam al-Mufradāt Alfād Al-Qur'ān, h.46. 
Wahyu Al-Qur'an turun pada awal manusia (tentu bukan hanya untuk laki-laki) merupakan anjuran memperoleh ilmu pengetahuan. Mayoritas ulama Al-Qur'an, sepakat bahwa wahyu Al-Qur'an yang turun pertama kali adalah lima ayat di Surah Al-'alaq/96, kemudian disusul awal ayat Surah al-Qalam/68;

Bacalah dengan (menyebut) nama Tuhanmu yang Menciptakan, 2. Dia telah menciptakan manusia dari segumpal darah. 3. Bacalah, dan Tuhanmulah yang Maha pemurah, 4. yang mengajar (manusia) dengan perantaran kalam, 5. Dia mengajar kepada manusia apa yang tidak diketahuinya.

Menurut Musthafa al-Maragi bahwa pengulangan kata iqra' pada ayat tersebut didasarkan pada alasan bahwa membaca itu tidak akan membekas dalam jiwa jiwa kecuali dengan diulang-ulang dan membiasakanya sebagaimana berlaku dalam tradisi. Dengan cara demikian bacaan tersebut menjadi milik orang yang membacanya. ${ }^{47}$

"Nun, demi kalam dan apa yang mereka tulis, 2. berkat nikmat Tuhanтu kaтu (Muhammad) sekali-kali bukan orang gila, 3. dan Sesungguhnya bagi kamu benar-benar pahala yang besar yang tidak putus-putusnya, 4. dan Sesungguhnya kamu benarbenar berbudi pekerti yang agung, 5. Maka kelak kamu akan melihat dan mereka (orang-orang kafir)pun akan melihat."

Dari ayat di atas tergambar dengan jelas betapa kitab suci AlQur'an memberi perhatian yang sangat serius kepada perkembangan ilmu pengetahuan yang di sampaikan dengan menggunakan redaksi "Iqra",. Makna perintah tersebut bukanlah hanya sebatas membaca dalam arti membaca teks, tetapi makna iqra' adalah membaca dengan melibatkan pemikiran dan pemahaman. ${ }^{48}$ Menurut al-Maragi secara harfiah ayat tersebut dapat diartikan jadilah engkau seorang yang yang dapat membaca berkat kekuasaan dan kehendak Allah yang telah menciptakanmu, walaupun sebelumnya engkau tidak dapat melakukanya. ${ }^{49}$ Dalam ayat pertama tersebut tidak dijelaskan objek apa yang harus di-iqra'.

${ }^{47}$ Ahmad Musthafa al-Maragi, Tafsīr Al-Marāḡ̄ (Beirut: Dār, al-fikr, t.th), h.99.

${ }^{48}$ Ar-Raghib al-Ishfahani, Mu'jam al-Mufradāt Alfād Al-Qur'ān, h.402.

${ }^{49}$ Ahmad Musthafa al-Maragi, Tafsìr Al-Marāgī, h.198. 
Hal ini mengandung arti bahwa apa saja yang dapat kita jangkau untuk diteliti, maka hal tersebut dapat menjadi objek iqra'. Di kalangan para mufasir ada ssatu kaidah yang menyatakan bahwa "apabila dalam suatu perintah apabila tidak disebutkan objeknya maka objeknya apa saja yang dapat dijangkau oleh perintah tersebut." ${ }^{50}$ Bagi perempuan dalam era modern sekarang ini justru harus lebih meningkatkan pendidikannya kejenjang yang lebih tinggi lagi (terutama ilmu agama), sebab dia memiliki beban yang sangat luar biasa di dalam menjaga keutuhan keluaraganya nanti.

5. Peran Perempuan dalam Bidang Politik

Islam sebagai agama yang benar di sisi Allah (QS. Ali 'Imran/3: 19) sangat peduli terhadap kesejahteraan kaum perempuan, menghargai sifat mereka, dan menghormati mereka. Menurut Mutahhari, ${ }^{51}$ Islam tidak meyakini satu jenis hak, satu jenis kewajiban, dan satu jenis hukuman bagi kaum laki-laki dan kaum perempuan dalam segala hal.

Islam memandang satu perangkat hak dan kewajiban serta hukuman lebih cocok bagi laki-laki dan satu perangkat lainnya lebih sesuai bagi perempuan. Sebagai hasilnya, dalam beberapa hal Islam mengambil sikap sama sehubungan dengan perempuan dan laki-laki, dan dalam hal-hal lain Islam mengambil sikap yang berbeda-beda. Prinsip keadilan sangat dijunjung tinggi dalam Islam. Keadilan yang diberikan Islam berupa kesetaraan dan kesederajatan tentang hak-hak dan kewajiban-kewajiban kepada kaum laki-laki dan kaum perempuan disesuaikan dengan tanggung jawabnya masing-masing. Jadi, Islam tidak memandang identik atau persis sama antara hak-hak laki-laki dan perempuan. Islam tidak pernah menganut preferensi dan diskriminasi yang menguntungkan laki-laki dan merugikan perempuan.

Islam juga menggariskan prinsip kesetaraan antara laki-laki dan perempuan, tetapi tidak persis sama atau identik. Kata "kesetaraan" (equality) telah memperoleh semacam kesucian, karena kata-kata ini telah mencakup pengertian keadilan dan tidak adanya diskriminasi. ${ }^{52}$ Dalam buku Women in Islam: A Discourse in Rights

${ }^{50}$ M. Quraish Shihab, Tafsir Al-Misbah, h.79.

${ }^{51}$ Murteza Mutahhari, The Rights of Women in Islam. "Wanita Dan HakHaknya Dalam Islam,” trans. M. Hashem (Bandung: Pustaka, 1985), h.90.

${ }^{52}$ Ibid. 
and Obligations (1999) Fatima Umar Nasif membagi hak-hak perempuan menjadi empat bagian, yaitu: 1) hak-hak sosial, 2) hak-hak keagamaan, 3) hak-hak politik, dan 4) hak-hak ekonomi.

Dalam bidang sosial, kaum perempuan dapat melakukan peran mereka dengan leluasa. Yang dimaksud hak-hak sosial di sini adalah hak-hak kaum perempuan untuk melaksanakan berbagai aktivitas, pekerjaan, dan profesi yang bermanfaat bagi masyarakatnya, baik dalam aspek duniawi maupun $u k h r a w i .{ }^{53}$ Islam mengakui pentingnya kaum perempuan dalam kehidupan masyarakat dan pengaruhnya dalam kehidupan politik. Karena itu kaum perempuan telah diberikan hak-hak politik yang mencerminkan status mereka yang bermartabat, terhormat, dan mulia dalam Islam. Di antara hak-hak politik perempuan yang diberikan Islam adalah hak untuk berbicara dan mengeluarkan pendapat. Hak ini dapat dipahami dari ayat Al-Qur'an yang memerintahkan kepada kaum Muslim untuk bermusyawarah dalam memecahkan segala urusan mereka. Ada dua ayat yang memerintahkan umat Islam untuk melakukan musyawarah, yaitu QS. al-Syūrā (42): 38 dan QS. Ali 'Imran (3): 159.

Islam tidak pernah melarang perempuan untuk aktif dalam bidang politik. Karena itu, pada masa Nabi Saw. kaum perempuan juga ikut terlibat dalam berbagai aktivitas publik atau politik. Di antara aktivitas politik yang dilakukan perempuan pada masa Nabi Saw. seperti yang diceritakan dalam hadits di antaranya adalah: 1) ikut berhijrah ke Habasyah bersama Nabi dan kaum laki-laki, 2) ikut hijrah ke Madinah bersama Nabi dan kaum laki-laki, 3) berbaiat dengan Nabi Saw. seperti yang ditegaskan dalam QS. al-Mumtahanah/60: 12, 4) ikut peduli terhadap masa depan politik negara yang menganut sistem kekhalifahan, dan 5) ikut menghadapi kezaliman salah seorang penguasa. ${ }^{54}$ Perempuan tidak ketinggalan untuk ambil peran dalam menjaga agama Allah. Misalnya dalam kasus Musailamah bin Habib al-Yamamy al-Kadzdzab, seorang pendusta yang mengaku sebagai

${ }^{53}$ Fatima Umar Nasif, Women in Islam: A Discourse in Rights and Obligations. Diterjemahkan Oleh Burhan Wirasubrata Dan Kundan D. Nuryakien Dengan Judul "Menggugat Sejarah Perempuan: Mewujudkan Idealisme Gender Sesuai Tuntunan Islam” (Jakarta: Cendekia Sentra Muslim, 2001), h.65.

54 'Abd al-Halim Abu Syuqqah, Tahrīr Al-Mar'ah F̄̄ 'Ashr al-Risālah. Diterjemahkan Oleh Chairul Halim Dengan Judul "Kebebasan Wanita" (Jakarta: Gema Insani Press, 1997), h.66-68. 
Nabi, ${ }^{55}$ perempuan memainkan aksinya untuk ikut menghancurkan sang nabi palsu. Adalah Ummu Amarah, Nusaibah binti Ka'b, perempuan yang berangkat ke Yamamah bersama kaum Muslimin untuk memberangus Musailamah. Keikutsertaan Nusaibah binti Ka'b ini menandakan bahwa peran perempuan adalah sejajar dengan lakilaki dalam hal membela Islam.

Hal ini membuat posisi politis perempuan juga terangkat dengan sendirinya Islam juga memberikan hak kepada perempuan untuk mendapatkan perlindungan dan perawatan. Allah Swt. memerintahkan orang-orang yang beriman untuk menolong kaum perempuan yang meninggalkan kampung halaman mereka melepaskan diri dari penganiayaan di negeri kaum kafir dan yang ingin menjadi anggota masyarakat Islam dengan menerima Islam sebagai agama mereka (QS. Al-MumThāhānah/60: 10). Orang-orang beriman wajib melindungi, menjaga, dan menegakkan hak-hak perempuan, wajib menjaga perempuan yang beriman dari ancaman orang-orang kafir yang akan membalas dendam terhadap mereka, dan wajib membayar ganti rugi kepada suami dari perempuan yang berhijrah jika suami itu memintanya.

Dengan demikian, kaum perempuan memperoleh hak-hak tersebut yang sekaligus menjadi kewajiban kaum lelaki. Hak sama yang diterima perempuan seperti halnya pria adalah dalam hal baiat (janji setia). Berdasarkan QS. Al-MumThāhānah (60): 12 Nabi Saw. diperintahkan untuk menerima janji setiap dari perempuan yang memenuhi persyaratan tertentu. Di antara persyaratan itu adalah: 1) tidak akan mempersekutuk an Allah, 2) tidak akan mencuri, 3) tidk berzina, 4) tidak membunuh anak-anak mereka, 5) tidak melakukan kebohongan yang besar, dan 6) tidak berbuat dusta. Dari sini jelaslah bahwa Nabi Saw. Menerima baiat kaum perempuan dan memperlakukan perempuan dan laki-laki secara sama.

Mengenai hak untuk menduduki jabatan penguasa bagi perempuan, para ulama berbeda pendapat. Ada beberapa pendapat mengenai hal ini. Sebagian ada yang membolehkan, ada juga yang melarang, bahkan mengharamkan sama sekali. Yang berpendapat

${ }^{55}$ Asma' Muhammad Ahmad Ziyadah, Daur Al-Mar'ah al-Siyasiy Fì 'Ahd al-Nabiy Wa al-Khulafa' al-Rasyidin, Diterjemahkan Oleh Kathur Suhardi Dengan Judul "PeraN Politik Wanita Dalam Sejarah Islam" (Jakarta: Pusta ka al-Kautsar, 2001), h.199. 
bahwa perempuan tidak layak menduduki jabatan ini, karena jabatan penguasa (kepala pemerinThāhān) dalam Islam berarti memikul tanggung jawab agama dan juga negara. Hal ini berlaku bagi kepala Negara, gubernur, komandan pasukan, dan lain-lain. Berdasarkan prinsip pembagian tugas dan tanggung jawab, jabatan penguasa seperti ini hanya dapat dipikul oleh laki-laki. Allah telah menciptakan laki-laki dan perempuan dengan kecenderungan fisik dan psikis yang berbeda untuk mempersiapkan mereka menjalankan peran yang berbeda namun sama pentingnya dalam masyarakat.

6. Peran Perempuan dalam Bidang Ekonomi

Pemikiran para ulama tentang "ar-Rijālu Qawwāmūna 'ala alNisā'," adalah tentang kepemimpinan keluarga yang sesungguhnya berkembang dalam kajian sosiologi keluarga karena adanya konsep strukturalisme keluarga, yang kemungkinan besar dipengaruhi strukturalisme secara umum, khususnya dalam kajian sosiologi politik. ${ }^{56}$

Sebagian ulama berpendapat bahwa tugas utama istri adalah melaksanakan aktifitas dalam rumah, yakni menunaikan kewajiban rumah tangga dan tugas-tugas keibuan dengan baik. Posisinya dalam keluarga adalah sebagai pendidik dan teladan bagi anak-anaknya serta pendamping bagi suaminya. Pengecualian bagi dirinya dalam hal keluar rumah adalah jika keadaan memaksanya atau mengharuskan hal itu. ${ }^{57}$

Sebagian ulama yang lain berpendapat bahwa tugas istri itu tidak hanya terbatas dalam rumahnya, yakni menjaga suami dan mendidik anak-anaknya. Akan tetapi, juga boleh keluar rumah untuk bekerja (untuk mencari nafkah). ${ }^{58}$

Fungsi ekonomi seorang istri memegang peranan penting dalam keluarga, karena merupakan faktor dasar untuk menunjang kebutuhan fisik kelurga. Akses perempuan terhadap peluang ekonomi dari berbagai sumber sangatlah besar. Dari berbagai penelitian yang ada, tampak bahwa pengelola ekonomi keluarga adalah istri. Pada

${ }^{56}$ M. F. Zenrif, Di Bawah Cahaya Al-Quran Cetak Biru Ekonomi Keluarga Sakinah (Malang: UIN Malang Press, 2006), h.8.

57 Khalid al-Namadi, Risalah Buat Wanita Muslimah (Jakarta: Pustaka Mantiq, t.th), h.183.

${ }^{58}$ Ibid., h.184. 
umumnya para istri yang mempunyai akses pada ekonomi mempunyai kontrol pula terhadap ekonomi keluarga. Makin tinggi akses ekonomi bagi perempuan, makin tinggi pula akses kontrolnya dan makin menonjol pula peranannya. Hal demikian dapat menciptakan kemandirian bagi perempuan sehingga memberi peluang untuk berperan sebagai pengambil keputusan dalam keluarga.

Perempuan (istri) yang mempunyai peluang ekonomi yang besar, besar pula kontrolnya terhadap pengelolaan atau penguasaan ekonomi dalam keluarga dan sekaligus mempunyai sifat kemandirian dan berperan pula dalam proses pengambilan keputusan, sehingga dapat mendorong terciptanya suasana kemitrasejajaran antara laki-laki dan perempuan dalam hak dan tanggung jawab dalam keluarga. ${ }^{59}$

Menurut Huzaemah, Perempuan diperbolehkan memberi nafkah kepada suami, anak dan rumah tangganya dari hasil jerih payahnya asalkan perempuan itu rela. Bahkan dalam keadaan suami miskin, istri boleh memberi zakat kepada suaminya, tetapi suami tidak boleh memberi zakat kepada istri sebab istri adalah tanggungannya. ${ }^{60}$

Pola pikir ini dikembangkan dengan menggunakan paradigma salaf, memandang bahwa hanya laki-laki yang berhak menjadi pemimpin keluarga karena berbagai alasan. ${ }^{61}$ Zamakhsyari misalnya, menafsirkan ayat tersebut dengan: "kaum laki-laki berfungsi sebagai yang memerintah dan melarang kaum perempuan sebagaimana pemimpin berfungsi terhadap rakyatnya". ${ }^{62}$ Dengan redaksi berbeda, al-Alusiy juga sama: "tugas kaum laki-laki adalah memimpin kaum perempuan, sebagaimana pemimpin memimpin rakyatnya, yakni dengan perintah, larangan dan yang semacamnya". ${ }^{63}$

59 Dadang S. Anshori, ed., Membincang Feminisme: Refleksi Wanita Muslimah Atas Peran Sosial Kaum Wanita (Bandung: Pustaka Hidayah, 1997), h.195.

${ }^{60}$ Ibid., h.196.

${ }^{61}$ M. F. Zenrif, Di Bawah Cahaya Al-Quran Cetak Biru Ekonomi Keluarga Sakinah, h.6.

62 Abu al-Qasim Mahmud ibn Umar al-Zamakhsyari, Al-Kasysyaf 'an Haqāiq al-Tanzīl Wa Uyun al-Aqāwil (Beirut: Dār al-Fikr, 1997), h.523.

${ }^{63}$ Abu al-Fadl Syihab al-Din al-Sayyid Mahmud al-Alusiy, Rūh Al-Ma'ānīy F̄̄ Tafsīr Al-Qur'ān al- 'Adzìm Wa al Sab'u al-Matsāniy (Beirut: Dār al-Fikr, t.th), h. 


\section{Kesimpulan}

Allah dalam menciptakan makhluk-Nya memiliki kemampuan kodrat dan keinginan terhadap pola atau bentuk akan ciptaan-Nya. Perempuan dengan pola bentuk tubuh yang berbeda dengan laki-laki. Oleh karena bentuknya berbeda dengan laki-laki, maka fungsinya di dunia ini juga berbeda dengan laki-laki. Namun demikian antara perempuan dan laki-laki diciptakan dengan dibekali kemampuan dan keahlian masing-masing. Perbedaan yang ada, tentunya bertujuan agar keduanya saling melengkapi. Perempuan merupakan makhluk individu dan sosial. Di samping menjadi seorang makhluk yang telah ditentukan bentuk biologisnya oleh Sang Kholik, tapi ia telah diberikan bekal untuk dapat mencerna apa yang ada di sekitarnya, mencermati, menganalisa dan mengamalkannya, sehingga dalam hal ini ia secara otomatis juga akan memiliki keinginan-keinginan. Keinginan wanita muslimah tentunya tidak lepas dari impiannya menjadi individu yang shalihah, sebagai anak, istri maupun sebagai ibu. Sementara peranannya sebagai makhluk sosial muncul rasa atau keinginan untuk dapat berproduksi dalam ranah publik, sosial dan politik. Dalam hal ini Islam telah mengaturnya, tidak ada nash yang membatasinya apabila perempuan tersebut memiliki kemampuan terjun ke wilayah publik. Namun demikian penulis berpendapat bahwa unsur prioritas dan tanggung jawab atas apa yang menjadi pilihan seorang perempuan untuk dapat aktif di ranah domestik harus benar-benar dapat dipertanggungjawabkan. Allah tidak mendeterminasi kaum Hawa, mereka dibebaskan untuk berbuat sekehendak hati mereka dengan melihat rambu-rambu syar'i yang telah ditentukan. Manusia adalah ciptaan dan seharusnyalah ia taat kepada Yang Menciptakan. [.] 
Abdul Aziz

\section{Daftar Pustaka}

'Abd al-Halim Abu Syuqqah. Tahrīr Al-Mar'ah Fī 'Ashr al-Risālah. Diterjemahkan Oleh Chairul Halim Dengan Judul “Kebebasan Wanita.” Jakarta: Gema Insani Press, 1997.

Abdullah bin Abdul Muhsin at-Turki. Tafsìr Muyassar. t.t: t.p, t.th.

Abdullah Yusuf 'Ali. The Meaning of Holy Al-Qur'ān, (. Beirut: Dār al-'Arabiyyah, t.th.

Abu 'Abdillah bin Muhammad Al-Bukhari. Shahih Al-Bukhārī. Singapura: Sulaiman, t.th.

Abu 'Abdillah Muhammad bin Ahmad al-Anshari Al-Qurtubi. AlJami' Li Ahkām Al-Qur'ān. Beirut: al-Maktabah al-Asriyyah, 2005.

Abu al-Fadl Syihab al-Din al-Sayyid Mahmud al-Alusiy. Rūh $A l$ Ma'ānīy Fì Tafsīr Al-Qur'ān al-'Adzìm Wa al Sab'u alMatsāniy. Beirut: Dār al-Fikr, t.th.

Abu al-Qasim Mahmud ibn Umar al-Zamakhsyari. Al-Kasysyaf 'an Haqāiq al-Tanzīl Wa Uyun al-Aqāwil. Beirut: Dār al-Fikr, 1997.

Abu Bakar bin Abi Syaibah. Al-Musannif, n.d.

Abu Daud. Sunan Abū Daud. t.t: t.p, t.th.

Abu Hayyan. Bahr Al-Muhit. t.t: t.p, t.th.

Abu Muhammad al-Andalusi. Al-Muharrir al-Wajiz. 2. t.t: t.p, t.th.

Ahmad Musthafa al-Maragi. Tafsìr Al-Marāgī. Beirut: Dār, al-fikr, t.th.

'Alā'uddin 'Ali bin Muhammad al-Khazin. Lubāb At-Ta'wīl Fī Ma'āni at-Tanzīl. t.t.: t.p, t.th.

Ar-Raghib al-Ishfahani. Mu'jam al-Mufradāt Alfād Al-Qur'ān. Beirut: Dār al-Fikr, t.th.

AS Hornby. "Oxford Dictionar," n.d.

Asma' Muhammad Ahmad Ziyadah. Daur Al-Mar'ah al-Siyasiy Fì 'Ahd al-Nabiy Wa al-Khulafa' al-Rasyidin, Diterjemahkan Oleh Kathur Suhardi Dengan Judul "PeraN Politik Wanita Dalam Sejarah Islam. ” Jakarta: Pusta ka al-Kautsar, 2001. 
Az-Zamakhsyari. Al-Kasysyāaf. Mesir: Musthafa al-Bābi al-Halabī, 1996.

Dadang S. Anshori, ed. Membincang Feminisme: Refleksi Wanita Muslimah Atas Peran Sosial Kaum Wanita. Bandung: Pustaka Hidayah, 1997.

Depag RI. "Tafsir Al-Qur'an Tematik.” Jakarta: Lajnah Pentashih Mushaf Al-Qur'an, 2009.

Departemen Pendidikan dan Kebudayaan. "Kamus Besar Bahasa Indonesia.” Jakarta: Balai Pustaka, 1995.

Fatima Umar Nasif. Women in Islam: A Discourse in Rights and Obligations. Diterjemahkan Oleh Burhan Wirasubrata Dan Kundan D. Nuryakien Dengan Judul "Menggugat Sejarah Perempuan: Mewujudkan Idealisme Gender Sesuai Tuntunan Islam. ”Jakarta: Cendekia Sentra Muslim, 2001.

Al-Hakim, al-Baihaki Dari Abu Rafi', (Jami' al-Hadīts, Juz 12)

Ibnu Faris. Mu'jam al-Maqāyis al-Lugah, n.d.

Ibnu Katsir. Tafsìr Al-Qur'ān al-Karìm. Beirut: Dār al-Fikr, 1980.

Ibrahim al-Qatān. Aisar At-Tafsìr r. t.t: t.p, t.th.

Julia Cleves Mosse. Gender Dan Pembangunan. Translated by $\mathrm{H}$. Silawati. Yogyakarta: Rifka An-Nisa WCC dan Pustaka Pelajar, 1996.

Khalid al-Namadi. Risalah Buat Wanita Muslimah. Jakarta: Pustaka Mantiq, t.th.

M. F. Zenrif. Di Bawah Cahaya Al-Quran Cetak Biru Ekonomi Keluarga Sakinah. Malang: UIN Malang Press, 2006.

M. Quraish Shihab. Tafsir Al-Misbah. Jakarta: Lentera Hati, 2002. . Wawasan Al-Qur'an. Bandung: Mizan, 1996.

Muhammad 'Abduh. Tafsīr Juz 'Amma. Beirut: Dār al-Fikr, n.d.

Muhammad at-Tahir Ibnu asy-Syur. Tahrīr Wa Tanwīr (. t.t: t.p, t.th. Muhammad bin Jarir Al-Thabariy. Jami' al-Bayān F̄ Ta'wīl AlQur'ān. 1. t.t: Muassasah ar-Risālah, t.th.

Muhammad Fuad Abdul Baqi. Mu'jam al-Mufahras, n.d.

Muhammada Sayid Tantawi. Al-Tafsìr al-Wasìt. t.t: t.p, t.th. 
Abdul Aziz

Murteza Mutahhari. The Rights of Women in Islam. Diterjemahkan Oleh Dengan Judul "Wanita Dan Hak-Haknya Dalam Islam." Translated by M. Hashem. Bandung: Pustaka, 1985.

Musdah Mulia. Membangun Surga Di Bumi; Kiat-Kiat Membina Keluarga Islam Di Bumi. Jakarta: PT Elex Me dia Komputindo, 2011.

Nasaruddin Umar. Bias Gender Dalam Pemahaman Islam. Yogyakarta: Gama Media, 2002.

Rasyid Ridha. Tafsīr Al-Manār. Beirut: Maktabah al-Qāhirah, t.th.

Sandra Scheneider. Women and The World. New York: Paulist Press, 1986.

Sayyid Qutub. F̄̄ Dzilāl Al-Qur'ān. Beirut: Dār asy-Syurūq, n.d.

Syafiq Hasyim, ed. "Gerakan Perempuan Dalam Islam: Perspektif Kesejarahan Kontemporer", Dalam Taswīr al-Afkār. V. Jakarta: Lakpesdam dan LTN-NU, 1999.

Tim Tafsir Depag RI. Tafsir Depag. Jakarta: Balitbang Agama, 2004. Wahbah Zuhaili. Tafsīr Wajīz. t.t: t.p, t.th. 